\title{
Household Electricity Generation as a Way of Energy Independence of States-Social Context of Energy Management
}

\author{
Shahin Bayramov ${ }^{1}$, Iurii Prokazov ${ }^{2}$, Sergey Kondrashev ${ }^{3} \mathbb{D}$ and Jan Kowalik ${ }^{4, *(D)}$ \\ 1 Department of Economics, Mingachevir State University (MSU), Mingechevir AZ4500, Azerbaijan; \\ rector@mdu.edu.az \\ 2 Renaissance Development Russia, 105264 Moscow, Russia; iurii.prokazov@gmail.com \\ 3 Department of Chemistry, I.M. Sechenov First Moscow State Medical University, 119991 Moscow, Russia; \\ Sk9262718531@gmail.com \\ 4 Faculty of Management, Technical University of Czestochowa, 42-201 Czestochowa, Poland \\ * Correspondence: janekowalik@yahoo.pl
}

check for updates

Citation: Bayramov, S.; Prokazov, I.; Kondrashev, S.; Kowalik, J.

Household Electricity Generation as a Way of Energy Independence of States-Social Context of Energy Management. Energies 2021, 14, 3407. https://doi.org/10.3390/en14123407

Academic Editors:

Miguel-Angel Tarancon and

Manuela Tvaronavičienè

Received: 16 March 2021

Accepted: 4 June 2021

Published: 9 June 2021

Publisher's Note: MDPI stays neutral with regard to jurisdictional claims in published maps and institutional affiliations.

Copyright: (c) 2021 by the authors. Licensee MDPI, Basel, Switzerland. This article is an open access article distributed under the terms and conditions of the Creative Commons Attribution (CC BY) license (https:// creativecommons.org/licenses/by/ $4.0 /)$.

\begin{abstract}
The purpose of this study was to determine the degree of influence of alternative options for generating electricity by households on the level of energy independence of countries. The research methodology was based on the use of correlation-regression analysis, as well as adapted non-linear optimization by choosing one of three scenarios for electricity generation by households for 20 countries. Regression analysis showed the dependence of a country's energy security on households' energy independence. It is determined that an increase in households' energy production helps to reduce the level of energy dependence in developed countries. However, for developing countries, there is no such interrelation. The solution of the formulated problem of nonlinear optimization for the studied countries has demonstrated that the criterion of energy dependence is superior to the criterion of a country's energy security. In the long term, this study can be deepened in the direction of assessing the effectiveness of household investment in electricity generation projects. The proposed results can be used by responsible persons in the field of economy and energy in order to determine the position of various policies, and use strategic levers and indicators that ensure an effective response to energy security challenges in the regional and global markets.
\end{abstract}

Keywords: correlation; energy dependence; energy efficiency management; energy security; scenario; social development

\section{Introduction}

Currently, the problem of resource and energy deficit is becoming increasingly urgent in the world. In today's realities with growing global energy problems, the issues of transition to alternative sources of energy supply are becoming increasingly common. Clean energy based on the latest technologies has long been identified as the basis for the future; therefore, the orientation towards oil, gas, and nuclear energy can lead to serious energy dependence on the largest suppliers of raw materials and today threatens the economic security of many countries [1]. Given the terrain complexity, low population concentrations, regulatory and organizational and administrative barriers, or high investment and operating costs, which may be unaffordable for utilities, grid promotion is not as profitable as alternatives, including increased autonomous energy production by households. The IEA estimates that for universal access to electricity by 2030, decentralized solutions are the least-cost option for the 60 percent of people who do not have access to electricity. Currently, decentralized electricity access solutions are scarce, but the pace of their development is accelerating every year. For example, the IEA estimates that 33 million people have access to electricity through off-grid renewables (excluding pico-solar, with 114 million users (according to IRENA)), with the accelerating rate of connection [2]. 
Energy is a key driver of economic growth, development, and well-being, and power systems need to maintain a constant balance between electricity demand and supply [3]. With the rapid development of distributed power generation technologies such as solar photovoltaic power, household power generation is gaining increasing attention due to decentralized energy autonomy and further economic benefits [4]. In today's world, an increasing number of countries, companies, and households are turning to alternative energy sources. Due to their geographical location, countries have the opportunity to freely use this direction, not to mention its environmental friendliness [5]. A Google Trends search for the key term "renewable energy" indicates that household electricity consumption is decreasing by 16.017 million $\mathrm{kWh}$ per unit increase in the search of the keyword "renewable". Google Trends search allows one to assess driving factors that are difficult to identify when analyzing with the use of various economic indicators [6]. However, it should be noted that special patterns of electricity consumption by a small part of electricity consumers, including households, cannot be ignored. It is essential for planning, operation, policy formulation, and decision making of the smart grid [7].

The development of the market for "green" energy production by private households makes a positive contribution to the efficiency of energy supply to states, increasing the environmental friendliness of the energy complex, ensuring the transition to the use of renewable energy sources, and reducing the use of fossil fuels [8]. At the same time, the pace of development of the private sector of renewable energy is not sufficient to make a significant contribution to the achievement of indicators of national plans and programs. The main reasons are doubts about the financial feasibility of such projects requiring state support, and insufficient incomes of the population of some countries, which do not allow accumulating funds for investment in renewable energy, along with the high cost of credit resources [9]. Alternative energy is an important component of the state's energy security, a component of sustainable development, and a means to improve the well-being of the population and the quality of life of people in general [10]. Its penetration into all spheres and industries should be stimulated not only at the national level, but also at the level of individual economic entities, in particular households, since their role in the growth of energy independence and energy efficiency can be very significant. Therefore, the study aimed to determine the role of households not only as potential energy producers, but also as a factor in increasing the level of energy security of countries, taking into account global trends.

\section{Literature Review}

In the modern scientific literature, there are studies of the effectiveness of power supply systems' technical design using renewable energy in remote settlements, taking into account their social needs. This design is capable of providing electricity not only to households, but also to medical centers, schools, churches, and cultural institutions. This indicates an additional important social effect on society [11]. Despite the global level of progress, there are regions in underdeveloped countries that do not have access to electricity or, if they do, suffer from frequent power outages. At the same time, it has been proven that the lack or low reliability of electricity supply affects the level of GDP [12]. To overcome this problem, government support is necessary, as it is in the interest of society as a whole. Ineffective policy in this direction leads to the fact that the rate of electrification remains low, despite significant investments in the nearby grid infrastructure. This pattern persists over time for both poor and relatively well-off households and businesses [13]. In developed countries, households' adoption of renewable energy is influenced by contextual and behavioral factors. For example, households that use renewable energy have lower energy consumption rates than other households. At the same time, they significantly reduce the load on the power grid. However, the key factor in the development of renewable energy production by households is their environmental motivation. Besides, the difference between households with photovoltaic installation before and after achieving energy system parity is determined, especially with regard 
to the effects of economic structure containment. A comprehensive support, including efficient technologies and environmentally motivated approaches to energy conservation, is required to reduce energy consumption [14]. Therefore, it is worth considering a different approach of modern researchers to the benefits of autonomous energy production by households as a factor of sustainable development of countries and regions. Regardless of whether electricity has become affordable and massively available for productive use, no country has moved from poverty to prosperity. Household electrification strategies must consider other development goals and opportunities to use electricity access to stimulate inclusive, climate-friendly, and sustainable economic activity $[15,16]$.

There are also studies for assessing the level of sustainable development based on an integrated indicator. At the same time, they demonstrate that the exclusion of the renewables financing indicator as a component of the integrated indicator does not have a significant impact on the final result [17]. To ensure the sustainability of the new energy supply models, it is important, in particular, to ensure that part of the supply chain and its associated benefits are local in nature (building appropriate competencies among households). It is also important that domestic financial institutions reach the necessary level of understanding and capacity to lend for off-grid energy and other types of equipment to households. The role of off-grid mini-grids, which is currently limited, should be expected to increase, especially when access initiatives are aimed at providing electricity to manufacturing and commercial activities, as well as to households. For sustainable development and effective functioning of autonomous mini-grids, an enabling environment is necessary, which includes specific policies and regulations, adapted financing mechanisms, institutional conditions, a focus on capacity building, and adaptation of technology [18].

This study raises the scientific issue of energy security of a country, thus it is necessary to define the qualitative characteristics of modern approaches to its definition and the relationship with the energy security of households.

At the same time, scientists offer their own interpretations of the concept of energy security. Special attention should be paid to those interpretations that are notable for their conciseness and content, such as:

- ensuring uninterrupted access to energy resources at an affordable price [19]; confidence that energy will be available and in the quantity and quality required under given economic conditions [20];

- $\quad$ protection of a state from energy threats [21];

- protection of citizens and a country as a whole from threats of deficiency of all types of energy resources [22];

- reliable and uninterrupted supply of electricity and fuel to consumers [23];

- $\quad$ security of the national economy and population; preventing any threats to the reliable supply of fuel and energy resources [24].

In general, there are two key areas in the modern literature:

- energy security is the timely, complete, and uninterrupted supply of quality fuel and energy to material production, non-production sphere, population, and other consumers [25];

- prevention of harmful effects of transportation, transformation and consumption of fuel and energy resources on the environment in the context of modern market relations, and trends and indicators of the global energy market [26].

Based on the essential characteristics of energy security of a state, the authors propose to define energy security of households as meeting (regardless of circumstances) the growing needs for energy resources (acceptable in price, quality, and assortment), taking into account social values. Thus, the authors emphasize that for countries, depending on their level of development, the value prerogatives of households in the context of energy security may differ. For some, it is a way of ensuring conditions for survival, while for others, it is a way of sustainable development, solving environmental and social problems. 
The participation of a state should be manifested in the initiation of the development of investment projects for the use of solar energy based on public-private partnerships [27,28]. At the state and regional levels, the popularization of the use of renewable energy sources among producers and users should be carried out. It is necessary to develop an economic mechanism (soft loans, interest-free loans, and other instruments) that will induce producers and users to replace traditional energy sources with renewable ones. An important financial instrument is the activation of banking programs for financing projects based on renewable energy sources [29].

In social terms, a state can manage the development of energy resources not only at the level of legislative institutions, but also financial ones in the implementation of energy projects with enterprises and receive income from their implementation [30]. Financial partnership in the development and implementation of renewable energy projects will bring income to a state budget, reduce greenhouse gas emissions into the atmosphere, improve the ecological state of the environment, create additional jobs, and contribute to the creation of the energy independence of a state [31].

The renewable energy sector creates different jobs in manufacturing, services, and construction and requires different qualifications and skills. Its development not only increases but also improves the quality of industrial jobs. At the same time, there is a trend towards a reduction in employment in the non-renewable energy sectors [32].

Energy security and energy independence of any country today are an important component of its sustainable development strategy. Political, economic, and infrastructural problems do not make it possible to provide the state with traditional energy sources sufficiently [33]. In such conditions, the role of renewable energy sources and alternative energy is especially growing. At the same time, the use of renewable energy sources helps to preserve traditional resources and the environment, and the introduction of a "green" tariff allows households to have an additional source of income, thus improving their quality of life [34]. Households greatly contribute to the development of alternative energy [35]. That is why it is very important to assess their role and opportunities in further increasing the level of energy independence and security of countries.

Among modern studies, not enough attention is paid to the analysis of independent renewable energy sources, which can become a start for understanding the very process of individual electrification of households. Most researchers mainly consider either the development of alternative energy in the country as a whole, or the peculiarities of its implementation by large enterprises. However, today households should also be taken into account, as they are the most flexible and prone to innovations, especially in the energy sector due to the rise in energy costs in recent years. This study aims to fill this gap by diagnosing the impact of household energy production on the energy efficiency of countries. This contributed to the formation of the research goal, which is to determine the degree of influence of alternative options for generating electricity by households on the level of energy independence of countries. Based on the formed research goal, the following key hypotheses can be identified:

- H1: the level of electricity generation by households affects country's energy security level;

- H2: the level of electricity production by households affects the level of country's energy dependence.

\section{Materials and Methods}

This study is driven by the need to identify those factors that confirm the impact of household electricity production on the energy dependence of countries. Household Energy Independence Index, Energy Security Index, and Country Energy Independence Index were used as effective factors for the analysis. The study was conducted on the basis of materials from 20 countries.

At the first stage of the study, countries were selected. The study analyzed the impact of households' energy generation on the energy independence of developed and 
developing countries; therefore, two groups of 10 countries each have been formed. The key criterion for the selection of these countries was belonging to the group of developed or developing countries, according to the United Nations methodology [36], including transition economies. The second criterion for the formation of the choice of countries was the leadership positions in their geographic region in terms of energy security, according to the rating of the Trilemma Energy Index $[37,38]$. The selection of countries for the study was based on a cross-criteria approach. Each of the selected countries is an important player in the energy market of its region, as well as a representative of developed or developing countries. This made it possible to substantiate the level of development of these countries and present different world regions in the study in the context of energy security. The availability of statistical data on the studied indicators was also taken into account. The selected developed countries were Belgium, Canada, Denmark, France, Hungary, Italy, Poland, Slovakia, the United Kingdom, the USA. The selected developing countries were Albania, Azerbaijan, China, Kenya, Mexico, Moldova, Namibia, Panama, Russia, and Serbia.

At the second stage, a regression analysis was carried out. Based on correlation analysis, to diagnose relationships, the calculation of pair correlation coefficients was carried out. As a result, coefficients were included that revealed the two-way relationships between the indicators under consideration. Besides, in the course of the study, an assessment of the impact of energy resources on the energy dependence of economies was carried out. To substantiate development priorities and formulate energy security strategies for each group of countries, the authors built models of interdependence of the Household Energy Independence Index, as the main monitoring indicator, and indicators of energy resources impact on the level of energy security and independence.

The authors propose the Households Energy Independence Index, which is calculated as the ratio of households' energy consumption volume in a country to the volume of households' renewable energy consumption based on IRENA data $[39,40]$. Household Energy Independence Index provides an opportunity to determine the level of households' autonomy based on the generation of energy from renewable sources.

The energy security index used in the study corresponds to the rating indicator constituting the Energy Trilemma Index of the World Energy Council [37]. For all the initial indicators, data for 2018 were available. Taking into account the fact that energy security is presented in the Energy Trilemma Index in the form of a rating, the study proposed to transform it into a coefficient using the formula:

$$
E S I_{i}=\frac{1}{E S T I_{i}}
$$

where $E S I_{i}$-Energy Security Index of $i$-th country; and $E S T I_{i}$-the place of $i$-th country in the Energy Security Index rating in the context of the Energy Trilemma Index.

The initial data for calculating the Household Energy Independence Index and Energy Security Index are given in Table 1.

Table 1. Initial data for determining the relationship between the level of energy security and household energy independence.

\begin{tabular}{|c|c|c|c|c|c|}
\hline Country & $\begin{array}{c}\text { Household Total } \\
\text { Final } \\
\text { Consumption }\end{array}$ & $\begin{array}{l}\text { Household Final } \\
\text { Renewable } \\
\text { Energy } \\
\text { Consumption }\end{array}$ & $\begin{array}{c}\text { Household } \\
\text { Energy } \\
\text { Independence } \\
\text { Index }\end{array}$ & $\begin{array}{l}\text { Country's Rank in } \\
\text { the Trilemma } \\
\text { Energy Index } \\
\text { (Energy Security) }\end{array}$ & $\begin{array}{c}\text { Energy Security } \\
\text { Index }\end{array}$ \\
\hline Belgium & 336,996 & 42,863 & 0.127 & 41 & 0.024 \\
\hline Canada & $1,504,610$ & 604,100 & 0.401 & 3 & 0.333 \\
\hline Denmark & 184,345 & 115,721 & 0.628 & 1 & 1 \\
\hline France & $1,543,673$ & 500,277 & 0.324 & 26 & 0.038 \\
\hline Hungary & 243,295 & 65,091 & 0.268 & 22 & 0.045 \\
\hline Italy & $1,337,934$ & 374,367 & 0.28 & 20 & 0.05 \\
\hline Poland & 818,268 & 134,002 & 0.164 & 69 & 0.014 \\
\hline Slovakia & 86,164 & 9183 & 0.107 & 29 & 0.034 \\
\hline
\end{tabular}


Table 1. Cont.

\begin{tabular}{|c|c|c|c|c|c|}
\hline Country & $\begin{array}{c}\text { Household Total } \\
\text { Final } \\
\text { Consumption }\end{array}$ & $\begin{array}{l}\text { Household Final } \\
\text { Renewable } \\
\text { Energy } \\
\text { Consumption }\end{array}$ & $\begin{array}{c}\text { Household } \\
\text { Energy } \\
\text { Independence } \\
\text { Index }\end{array}$ & $\begin{array}{l}\text { Country's Rank in } \\
\text { the Trilemma } \\
\text { Energy Index } \\
\text { (Energy Security) }\end{array}$ & $\begin{array}{c}\text { Energy Security } \\
\text { Index }\end{array}$ \\
\hline The United Kingdom & $1,632,475$ & 209,246 & 0.128 & 18 & 0.056 \\
\hline The USA & $11,343,716$ & $1,406,490$ & 0.123988 & 7 & 0.143 \\
\hline Albania & 21,227 & 16,784 & 0.790688 & 98 & 0.01 \\
\hline Azerbaijan & 137,704 & 2441 & 0.017726 & 38 & 0.026 \\
\hline China & $14,516,180$ & $4,358,382$ & 0.300243 & 43 & 0.023 \\
\hline Kenya & 517,572 & 122,338 & 0.236369 & 34 & 0.029 \\
\hline Mexico & 755,759 & 287,200 & 0.380015 & 65 & 0.015 \\
\hline Moldova & 58,113 & 31,947 & 0.549741 & 115 & 0.009 \\
\hline Namibia & 17,836 & 12,290 & 0.689065 & 93 & 0.011 \\
\hline Panama & 23,907 & 15,890 & 0.664669 & 92 & 0.011 \\
\hline Russia & $6,206,973$ & 16,3371 & 0.026321 & 16 & 0.063 \\
\hline Serbia & 118,780 & 45,591 & 0.383829 & 60 & 0.017 \\
\hline
\end{tabular}

Source: compiled by the authors based on statistical data [37-39]; calculated by the authors.

The authors proposed an Index of a country's energy independence, which integrates the following key indicators: Energy intensity per unit of GDP, Net energy imports, Total energy supply (TES) per capita, Energy share from renewable energy sources, and Energy production to consumption ratio. The integral indicator is the average value of its normalized components:

$$
k_{i}^{\text {norm }}=\left\{\begin{array}{l}
\frac{k_{i}-k_{i}^{\text {min }}}{k_{i}^{\text {max }}-k_{i}^{\text {min }}}, k_{i} \rightarrow \max \\
\frac{k_{i}-k_{i}^{\text {max }}}{k_{i}^{\text {min }}-k_{i}^{\text {max }}}, k_{i} \rightarrow \text { min }
\end{array}\right.
$$

where $k i$ is the $i$-th indicator of integral index, $i=\{1,2,3,4,5,6\}$;

$k_{i}^{m i n}$ is the minimum value of the $i$-th indicator;

$k_{i}^{\text {max }}$ is the maximum value of the $i$-th indicator;

$k_{i}^{\text {norm }}$ is the normalized value of the $i$-th indicator [41].

The Energy Independence Index was calculated using the formula:

$$
S I I_{i}=\sqrt{E I_{i}^{2}+N E I_{i}^{2}+T E S_{i}^{2}+R E S S_{i}^{2}+R E P S_{i}^{2}},
$$

where $S I I_{i}$-Energy Independence Index of $i$-th country; $E I_{i}$-normalized value of Energy intensity per unit of GDP of $i$-th country; $N E I_{i}$-normalized value of Net energy imports of $i$-th country; TES $i$-normalized value of Total energy supply per capita of $i$-th country; $R E S S_{i}$-normalized value of Energy share from renewable energy sources of $i$-th country; and $R E P S_{i}$-normalized value of Energy production to consumption ratio of $i$-th country.

The initial data for calculating the Energy Independence Index are shown in Table 2.

To assess the impact of energy generation by households, the Social Content Index (SCI) is proposed, which is formed on the basis of the social components of The Legatum Prosperity Index (Social Capital-SC, Living Conditions-LC, Health-H, and Natural Environment-NE). These indicators are able to demonstrate the degree of the social context of the development of the studied countries. The social content index is calculated using the formula:

$$
S C I_{i}=\frac{1}{\left(S C_{i}+L C_{i}+H_{i}+N E_{i}\right) / 4}
$$

Using this indicator, the social context in this study was determined. The initial data are given in Table 3. 
Table 2. Initial data for determining the level of energy independence of the studied countries.

\begin{tabular}{|c|c|c|c|c|c|c|}
\hline Country & $\begin{array}{c}\text { Energy } \\
\text { Intensity per } \\
\text { Unit of GDP, } \\
\text { MJ/USD }\end{array}$ & $\begin{array}{c}\text { Net Energy } \\
\text { Imports, Mtoe }\end{array}$ & $\begin{array}{c}\text { Total Energy } \\
\text { Supply (TES) } \\
\text { per Capita, } \\
\text { Toe/Capita }\end{array}$ & $\begin{array}{c}\text { Energy Share } \\
\text { from } \\
\text { Renewable } \\
\text { Energy } \\
\text { Sources, \% }\end{array}$ & $\begin{array}{c}\text { Energy } \\
\text { Production to } \\
\text { Consumption } \\
\quad \text { ratio }\end{array}$ & $\begin{array}{c}\text { Energy } \\
\text { Independence } \\
\text { Index }\end{array}$ \\
\hline Belgium & 4.8 & 52.9 & 4.7 & 6.69 & 0.17 & 0.70 \\
\hline Canada & 7.6 & -227.6 & 8.0 & 27.57 & 1.56 & 1.36 \\
\hline Denmark & 2.6 & 4.5 & 2.9 & 26.72 & 0.82 & 1.81 \\
\hline France & 2.2 & 119.5 & 3.7 & 11.26 & 0.51 & 1.10 \\
\hline Hungary & 4.2 & 15.5 & 2.7 & 3.40 & 0.35 & 0.71 \\
\hline Italy & 3.0 & 121.9 & 2.5 & 16.33 & 0.22 & 1.00 \\
\hline Poland & 4.2 & 47.2 & 2.8 & 6.18 & 0.55 & 0.73 \\
\hline Slovakia & 4.4 & 10.9 & 3.2 & 7.66 & 0.33 & 0.71 \\
\hline $\begin{array}{l}\text { The United } \\
\text { Kingdom }\end{array}$ & 2.8 & 66.5 & 2.6 & 13.04 & 0.66 & 0.88 \\
\hline The USA & 5.1 & 80.7 & 6.8 & 8.47 & 0.95 & 1.09 \\
\hline Albania & 2.9 & 0.5 & 0.8 & 37.20 & 0.79 & 1.13 \\
\hline Azerbaijan & 3.8 & -40.7 & 1.5 & 2.87 & 3.93 & 1.35 \\
\hline China & 6.1 & 700.5 & 2.3 & 12.18 & 0.80 & 0.57 \\
\hline Kenya & 3.0 & 6.0 & 0.5 & 71.80 & 0.26 & 1.40 \\
\hline Mexico & 2.0 & 29.4 & 1.5 & 6.47 & 0.79 & 1.15 \\
\hline Moldova & 7.3 & 3.3 & 1.2 & 26.10 & 0.00 & 0.64 \\
\hline Namibia & 3.5 & 1.6 & 0.8 & 28.10 & 0.13 & 0.98 \\
\hline Panama & 2.1 & 8.3 & 1.0 & 22.80 & 0.19 & 1.14 \\
\hline Russia & 8.3 & -701.3 & 5.3 & 5.72 & 1.92 & 1.50 \\
\hline Serbia & 6.1 & 5.4 & 2.2 & 19.90 & 0.67 & 0.76 \\
\hline
\end{tabular}

Source: compiled by the authors based on statistical data [40,42]; the authors' own calculations.

Table 3. Initial data for determining the Social Content Index of the studied countries.

\begin{tabular}{|c|c|c|c|c|c|}
\hline Country & $\begin{array}{l}\text { Social Capital } \\
\text { Rank }\end{array}$ & $\begin{array}{c}\text { Living Conditions } \\
\text { Rank }\end{array}$ & Health Rank & $\begin{array}{c}\text { Natural } \\
\text { Environment Rank }\end{array}$ & $\begin{array}{l}\text { Social Content } \\
\text { Index }\end{array}$ \\
\hline Belgium & 45 & 18 & 24 & 47 & 0.032 \\
\hline Canada & 10 & 16 & 25 & 15 & 0.056 \\
\hline Denmark & 2 & 1 & 8 & 10 & 0.158 \\
\hline France & 41 & 17 & 16 & 16 & 0.055 \\
\hline Hungary & 90 & 37 & 52 & 30 & 0.023 \\
\hline Italy & 56 & 24 & 17 & 48 & 0.032 \\
\hline Poland & 111 & 31 & 40 & 62 & 0.022 \\
\hline Slovakia & 76 & 33 & 43 & 12 & 0.034 \\
\hline $\begin{array}{l}\text { The United } \\
\text { Kingdom }\end{array}$ & 14 & 8 & 23 & 24 & 0.052 \\
\hline The USA & 16 & 29 & 59 & 25 & 0.029 \\
\hline Albania & 120 & 90 & 69 & 73 & 0.014 \\
\hline Azerbaijan & 125 & 70 & 66 & 148 & 0.010 \\
\hline China & 34 & 66 & 21 & 147 & 0.013 \\
\hline Kenya & 64 & 132 & 115 & 129 & 0.008 \\
\hline Mexico & 118 & 81 & 37 & 78 & 0.016 \\
\hline Moldova & 105 & 74 & 96 & 134 & 0.010 \\
\hline Namibia & 60 & 114 & 126 & 77 & 0.010 \\
\hline Panama & 70 & 78 & 45 & 36 & 0.023 \\
\hline Russia & 101 & 57 & 103 & 44 & 0.014 \\
\hline Serbia & 96 & 47 & 72 & 99 & 0.013 \\
\hline
\end{tabular}

Source: compiled by the authors based on statistical data [43]; the authors' own calculations.

The third stage of the study is a modeling based on a scenario approach to diagnosing the relationship between electricity production by households and the energy dependence of countries with an implemented economic and mathematical method. This method 
makes it possible to achieve high accuracy in solving nonlinear optimization problems using the hierarchical analysis of Thomas L. Saaty [44]. To conduct the study by solving the problem of nonlinear optimization for the scenario of electricity production by households in the studied countries, the following steps were used:

1. Determination of the regression dependence of energy security (y1), independence (y2), social content (y3) from the Household Energy Independence Index (x) in the studied countries.

2. Paired linear regression models were used, which revealed the relationship between the studied factors: $y 1=a 1+b 1 \times x, y 2=a 2+b 2 \times x$. The variable $x$ was replaced with the obtained values in the equations.

3. Formation of scenarios using $\mathrm{t}-\mathrm{a}$ time period based on the data being simulated. Three scenarios were proposed. According to each of them, the Household Energy Independence Index is increased by $10 \%$.

4. Determination of the weight of the optimality criteria: energy security and independence were ranked in accordance with their importance for each of the studied groups of countries, according to the Thomas L. Saaty scale.

5. Assessment based on generated scenarios. Moreover, the share of $\mathrm{y}_{\mathrm{ESI}}$ and $\mathrm{y}_{\mathrm{EII}}$ for each scenario is a weighted arithmetic mean. Thus, $E S I_{s c i}^{n o r m}$ and $E I I_{s c i}^{n o r m}$ were determined.

6. Determination for each scenario of a weighted sum of energy independence indicators: $E S I_{s c i}^{w s}=E S I_{s c i}^{n o r m} *$ weight, and the weighted sum of energy security indicators were determined similarly-ESI $I_{s c i}^{w s}=E S I_{s c i}^{n o r m} *$ weight.

7. Conducting a hierarchical synthesis $\left(H S_{s c i}=E S I_{s c i}^{n o r m} * E I I_{s c i}^{n o r m}\right)$. The results obtained were compared, and the scenario with the maximum value was selected according to the hierarchical synthesis [44].

\section{Results}

Based on a comparison of the level of total energy consumption by households (HTFC) and their consumption of renewable energy (HFREC) (Figure 1), it can be argued that for most of the studied countries, there is a fairly high relationship between these indicators. Analysis of variance results are shown in Table 4.
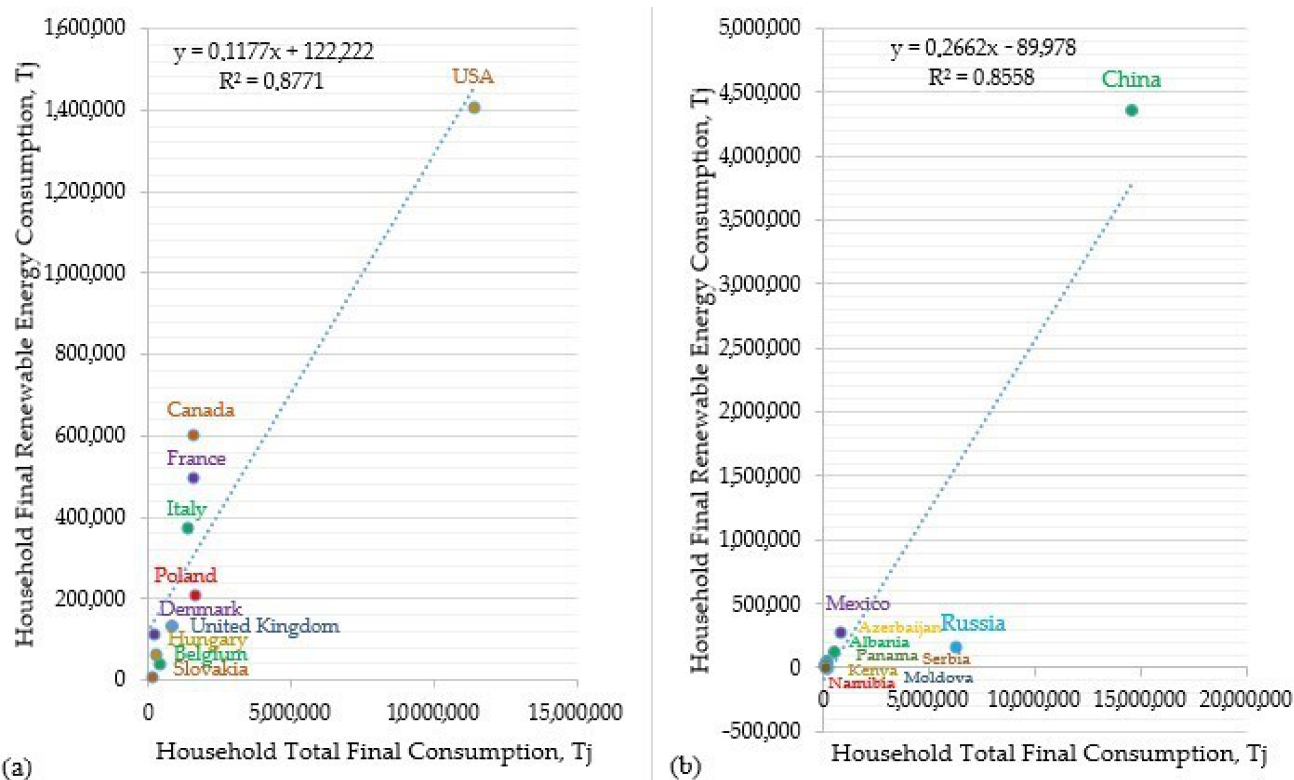

Figure 1. Dependence of total energy consumption and consumption of energy from renewable sources by households in the studied developed (a) and developing (b) countries. Source: generated by the authors. 
Table 4. Indicators of analysis of variance for total energy consumption and consumption of renewable energy by households.

\begin{tabular}{|c|c|c|c|c|c|c|c|}
\hline Group & Indicator & df & SS & MS & $\mathbf{F}$ & F Sign & \\
\hline \multirow{3}{*}{$\begin{array}{l}\text { Developed } \\
\text { countries }\end{array}$} & Regression & 1 & $1,418,090,185,502$ & $14,18,090,185,502$ & 57 & 0.0001 & \\
\hline & Residue & 8 & $1,98,691,189,356$ & $24,836,398,670$ & & & \\
\hline & Total & 9 & $1,616,781,374,858$ & & & & \\
\hline \multirow{3}{*}{$\begin{array}{l}\text { Developing } \\
\text { countries }\end{array}$} & Regression & 1 & $14,177,173,812,816$ & $14,177,173,812,816$ & 47 & 0.0001 & \\
\hline & Residue & 8 & $2,389,700,476,144$ & $298,712,559,518$ & & & \\
\hline & Total & 9 & $16,566,874,288,960$ & & & & \\
\hline Group & Factor & Coefficients & Standard error & t-stat & $p$-value & Lower $95 \%$ & Higher $95 \%$ \\
\hline \multirow{2}{*}{$\begin{array}{l}\text { Developed } \\
\text { countries }\end{array}$} & Y-intersection & $122,221.9493$ & $57,980.4383$ & 2.1080 & 0.0681 & $-11,481.1812$ & $255,925.0799$ \\
\hline & X (HTFC) & 0.1177 & 0.0156 & 7.5563 & 0.0001 & 0.0817 & 0.1536 \\
\hline \multirow{2}{*}{$\begin{array}{l}\text { Developing } \\
\text { countries }\end{array}$} & $\begin{array}{l}\text { Y-intersection } \\
\text { (HFREC) }\end{array}$ & $-89,978.4280$ & $19,3250.2207$ & -0.4656 & 0.6539 & $-53,5614.2362$ & $355,657.3801$ \\
\hline & X (HTFC) & 0.2662 & 0.0386 & 6.8892 & 0.0001 & 0.1771 & 0.3553 \\
\hline
\end{tabular}

Source: the authors' calculations.

The established relationship between the level of total energy consumption by households and their consumption of renewable energy is confirmed by a number of control points. The $p$-value for variable $\mathrm{X}$ (HTFC) is less than 0.05 . At the same time, Fcrit $<\mathrm{F}$ is also a positive characteristic, namely, for developed countries $5.35<22.62$, and for developing countries $5.35<12.75$. The adequacy of the formed equations is confirmed by the Student's criterion (tcrit $<$ tobs): for developed countries $2.31<4.76$, and for developing countries $2.31<3.57$.

At the same time, for developed countries, there is a higher degree of dependence $\left(R^{2}=0.8771\right)$ compared to developing countries $\left(R^{2}=0.8558\right)$.

The increase in energy consumption by households entails an increase in the consumption of renewable energy, which, presumably, the households themselves generate. Therefore, for both developed and developing countries, the trend is the development of household electricity production from renewable sources. At the same time, the quality of consumption changes, since households in this way substitute their part of the consumed energy. In the two groups of studied countries, the United States and China are clearly distinguished. Indicators of total energy consumption and renewable energy consumption by households of the US and China significantly exceed those of other countries. The US and China are leaders in both household energy consumption and renewable energy production.

To determine the relationship between the level of energy independence of households (Household Energy Independence Index-HEII) and a country's Energy Security Index (ESI), a regression analysis was carried out. Analysis of variance results are shown in Table 5.

Table 5. Indicators of analysis of variance for the Energy Security Index.

\begin{tabular}{|c|c|c|c|c|c|c|c|}
\hline Group & Indicator & df & SS & MS & $\mathbf{F}$ & F sign & \\
\hline \multirow{3}{*}{$\begin{array}{c}\text { Developed } \\
\text { countries }\end{array}$} & Regression & 1 & 0.6207 & 0.6207 & 22.6179 & 0.0014 & \\
\hline & Residue & 8 & 0.2195 & 0.0274 & & & \\
\hline & Total & 9 & 0.8402 & & & & \\
\hline \multirow{3}{*}{$\begin{array}{l}\text { Developing } \\
\text { countries }\end{array}$} & Regression & 1 & 0.0014 & 0.0014 & 12.7470 & 0.0073 & \\
\hline & Residue & 8 & 0.0009 & 0.0001 & & & \\
\hline & Total & 9 & 0.0024 & & & & \\
\hline Group & Factor & Coefficients & Standard error & t-stat & $p$-value & Lower 95\% & Higher 95\% \\
\hline \multirow{2}{*}{$\begin{array}{c}\text { Developed } \\
\text { countries }\end{array}$} & $\begin{array}{l}\text { Y-intersection } \\
\text { (ESI) }\end{array}$ & -0.2313 & 0.1000 & -2.3126 & 0.0495 & -0.4619 & -0.0007 \\
\hline & X (HEII) & 1.5888 & 0.3341 & 4.7558 & 0.0014 & 0.8184 & 2.3592 \\
\hline \multirow{2}{*}{$\begin{array}{l}\text { Developing } \\
\text { countries }\end{array}$} & $\begin{array}{l}\text { Y-intersection } \\
\text { (ESI) }\end{array}$ & 0.0404 & 0.0063 & 6.4158 & 0.0002 & 0.0259 & 0.0549 \\
\hline & X (HEII) & -0.0471 & 0.0132 & -3.5703 & 0.0073 & -0.0775 & -0.0167 \\
\hline
\end{tabular}


The dependence of the energy security of the studied countries on the level of the Household Energy Independence Index can be graphically interpreted using equations (Figure 2). Their applicability is confirmed by the $p$-value, the value of which for the variable $X$ (HEII) is less than 0.05 . The adequacy of the formed equations is characterized by Fcrit $<$ F, namely, for developed countries $5.32<57.1$, and for developing countries $5.32<47.46$. Applicability is also confirmed by the Student's criterion (tcrit $<$ tobs): for developed countries $2.31<7.56$, and for developing countries $2.31<6.89$.

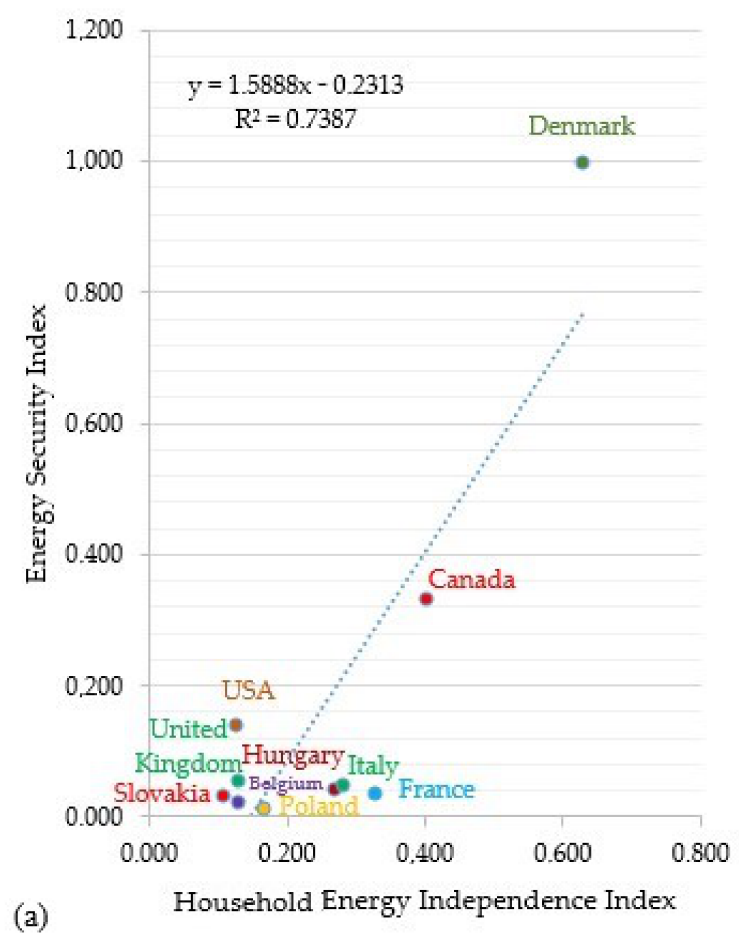

(a)

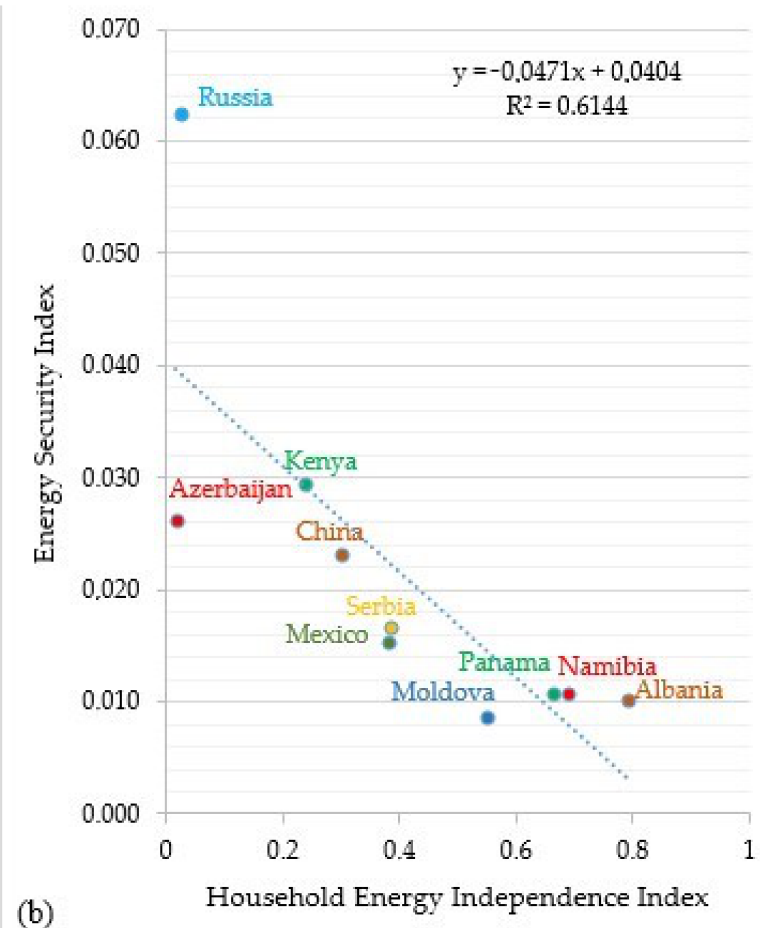

Figure 2. The relationship between a country's energy security and a level of energy independence of households in the studied developed (a) and developing (b) countries. Source: generated by the authors.

Almost all countries are characterized by a dependence of a country's energy security on households' energy independence. Household energy production influences import independence and energy storage capacity in a country. Moreover, the degree of this dependence for developed and developing countries is approximately at the same level. It is paradoxical that in developed countries an increase in the household energy independence index contributes to an increase in the level of energy security, while in developing countries, an increase in household energy independence leads to a decrease in the energy security index. This is primarily due to the fact that most of the studied developing countries have a fairly high level of energy security, but at the same time, very low indicators of the Household Energy Independence Index (Azerbaijan and Russia). The average household energy independence index in developing countries is almost two times lower (0.255) than in developed countries (0.404).

The results of the analysis of variance for the relationship between the Energy Independence Index (EII) and the Household Energy Independence Index (HEII) are shown in Table 6.

The relationship between the level of energy independence and the Household Energy Independence Index is confirmed by the $p$-value for the variable $X(p$-value $<0.05)$ for developed countries, but for developing countries, the $p$-value for HEII is greater than 0.05 (0.2455). At the same time, a positive characteristic of the equation for developed countries is the value Fcrit $<\mathrm{F}$, namely for $(5.35<27.07)$; for developing countries this criterion has no confirmation $(5.35>1.57)$. The adequacy of the equations formed on the 
basis of the Student's criterion (tcrit $<$ tobs) is confirmed only for developed countries (2.31 $<5.2$ ). For developing countries, the situation is reversed, with $2.31>1.25$. Based on this, it can be stated that there is no relationship between the factors under study for developing countries. A graphic interpretation of the results obtained is shown in Figure 3.

Table 6. Indicators of analysis of variance for the Energy Independence Index.

\begin{tabular}{|c|c|c|c|c|c|c|c|}
\hline Group & Indicator & df & SS & MS & $\mathbf{F}$ & F sign & \\
\hline \multirow{3}{*}{$\begin{array}{l}\text { Developed } \\
\text { countries }\end{array}$} & Regression & 1 & 0.8932 & 0.8932 & 27.0745 & 0.0008 & \\
\hline & Residue & 8 & 0.2639 & 0.0330 & & & \\
\hline & Total & 9 & 1.1571 & & & & \\
\hline \multirow{3}{*}{$\begin{array}{l}\text { Developing } \\
\text { countries }\end{array}$} & Regression & 1 & 0.1518 & 0.1518 & 1.5705 & 0.2455 & \\
\hline & Residue & 8 & 0.7734 & 0.0967 & & & \\
\hline & Total & 9 & 0.9252 & & & & \\
\hline Group & Factor & Coefficients & Standard error & t-stat & $p$-value & Lower 95\% & Higher $95 \%$ \\
\hline \multirow{2}{*}{$\begin{array}{c}\text { Developed } \\
\text { countries }\end{array}$} & $\begin{array}{l}\text { Y-intersection } \\
\text { (EII) }\end{array}$ & 0.5232 & 0.1097 & 4.7698 & 0.0014 & 0.2702 & 0.7761 \\
\hline & X (HEII) & 1.9060 & 0.3663 & 5.2033 & 0.0008 & 1.0613 & 2.7507 \\
\hline \multirow{2}{*}{$\begin{array}{l}\text { Developing } \\
\text { countries }\end{array}$} & $\begin{array}{l}\text { Y-intersection } \\
\text { (EII) }\end{array}$ & 1.2573 & 0.1840 & 6.8322 & 0.0001 & 0.8329 & 1.6816 \\
\hline & X (HEII) & -0.4827 & 0.3852 & -1.2532 & 0.2455 & -1.3708 & 0.4055 \\
\hline
\end{tabular}

Source: the authors' calculations.
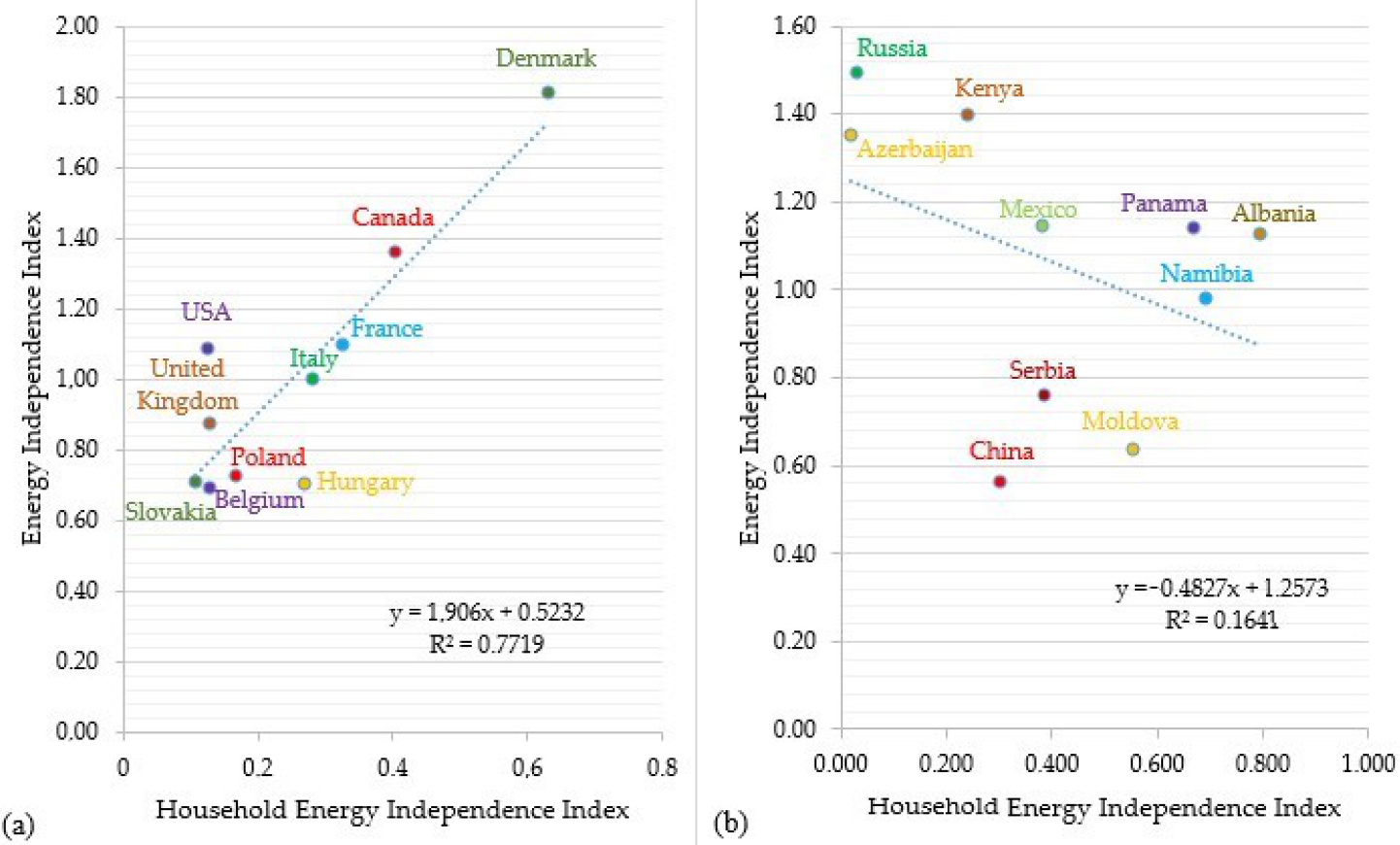

Figure 3. Relationship between the level of energy independence of countries on the index of energy independence of households of the studied developed (a) and developing (b) countries. Source: generated by the authors.

Increasing energy production by households to meet their needs helps reduce energy dependence in developed countries. This is confirmed by the value $R^{2}=0.7719$. For developing countries, this dependence is absent, since $R^{2}=0.1641$. Therefore, the degree of influence of the studied indicators was determined only for developed countries.

Similarly, the impact of energy generation by households on the level of social development of the studied countries was assessed using the Social Content Index. The results of the analysis of variance are shown in Table 7. 
Table 7. Indicators of analysis of variance for the Social Content Index.

\begin{tabular}{|c|c|c|c|c|c|c|c|}
\hline Group & Indicator & df & SS & MS & F & F sign & \\
\hline \multirow{3}{*}{$\begin{array}{l}\text { Developed } \\
\text { countries }\end{array}$} & Regression & 1 & 0.01024 & 0.01024 & 19.18578 & 0.00235 & \\
\hline & Residue & 8 & 0.00427 & 0.00053 & & & \\
\hline & Total & 9 & 0.01451 & & & & \\
\hline \multirow{3}{*}{$\begin{array}{l}\text { Developing } \\
\text { countries }\end{array}$} & Regression & 1 & 0.00002 & 0.00002 & 1.07689 & 0.32974 & \\
\hline & Residue & 8 & 0.00014 & 0.00002 & & & \\
\hline & Total & 9 & 0.00016 & & & & \\
\hline Group & Factor & Coefficients & Standard error & t-stat & $p$-value & Lower 95\% & Higher $95 \%$ \\
\hline \multirow{2}{*}{$\begin{array}{l}\text { Developed } \\
\text { countries }\end{array}$} & $\begin{array}{l}\text { Y-intersection } \\
\text { (SCI) }\end{array}$ & -0.0028 & 0.0140 & -0.2010 & 0.8457 & -0.0350 & 0.0294 \\
\hline & X (HEII) & 0.2041 & 0.0466 & 4.3802 & 0.0023 & 0.0967 & 0.3116 \\
\hline \multirow{2}{*}{$\begin{array}{l}\text { Developing } \\
\text { countries }\end{array}$} & $\begin{array}{l}\text { Y-intersection } \\
\text { (SCI) }\end{array}$ & 0.0110 & 0.0025 & 4.4565 & 0.0021 & 0.0053 & 0.0110 \\
\hline & X (HEII) & 0.0054 & 0.0052 & 1.0377 & 0.3297 & -0.0066 & 0.0054 \\
\hline
\end{tabular}

Source: the authors' calculations.

The dependence of the social content of the development of the studied countries on the level of the Household Energy Independence Index is graphically interpreted using equations (Figure 4). The applicability of the obtained equation is confirmed only for developed countries, since $\mathrm{R}^{2}=0.7057$, and $p$-value for the variable $\mathrm{X}$ (HEII) is less than 0.05 . The adequacy of the formed equation for developed countries is characterized by Fcrit < F $(5.32<19.19)$, as well as Student's tcrit < tobs $(2.31<4.38)$. For developing countries, this relationship is practically absent and demonstrates the lack of adequacy of the formed equation.
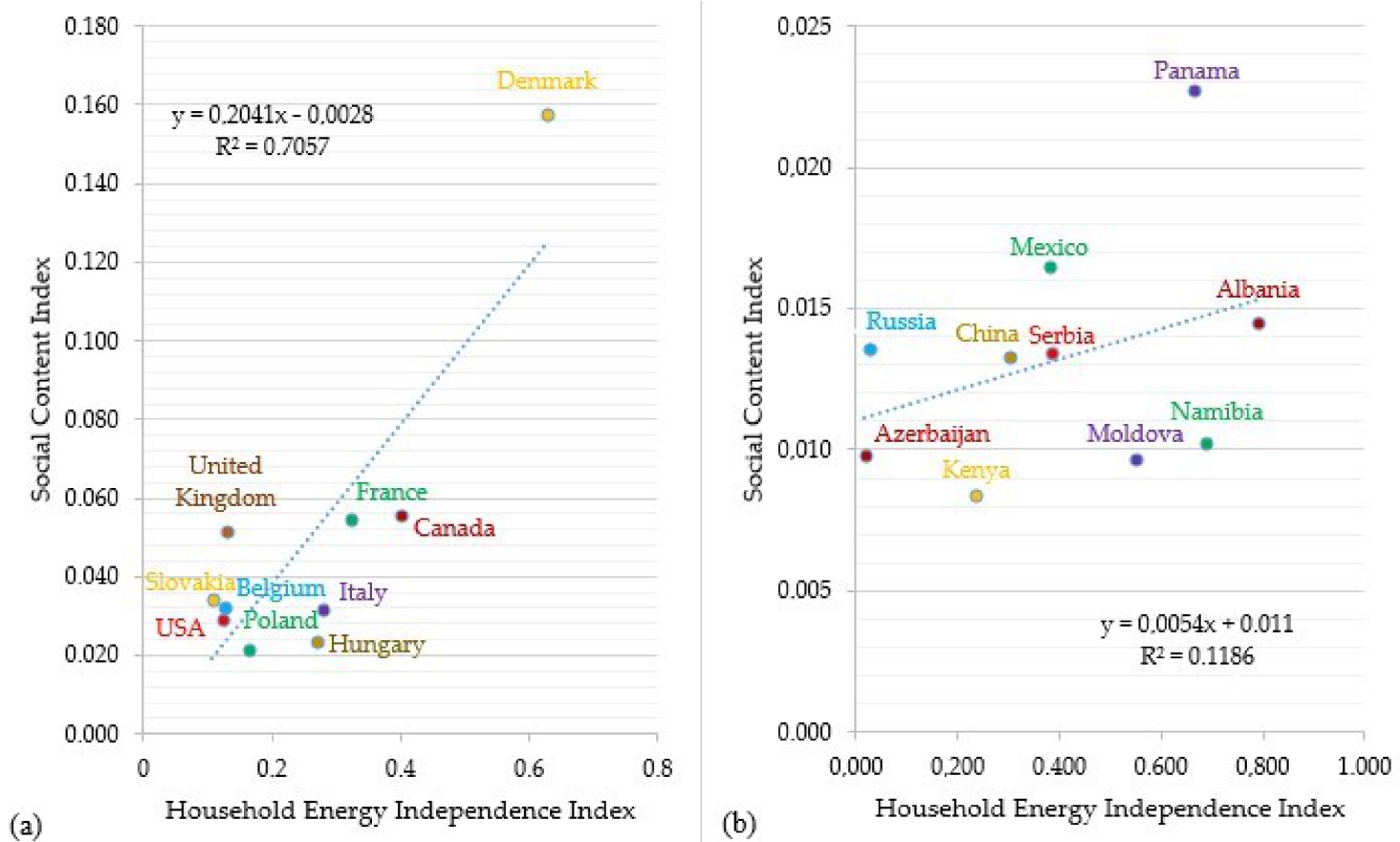

Figure 4. Relationship between Social Content Index of countries and the index of energy independence of households of the studied developed (a) and developing (b) countries. Source: generated by the authors.

Thus, it can be argued that increasing the volume of renewable energy generation by households is important for developed countries. For developing countries, household energy from renewable sources does not have a significant impact on social capital, health, living conditions, and the external environment.

Key indicators of modeling results for three scenarios of growth in electricity generation by households in the studied countries are shown in Table 8 . At the same time, it was 
assumed that the level of the energy independence index of households corresponds to the level of electricity generation to meet their needs. The first scenario assumes an increase in the average actual index of the energy independence of households (the level of electricity generation) by $10 \%$. The second scenario assumes an increase in electricity generation by households by $20 \%$. The third scenario provides for an increase in household electricity production by $30 \%$.

Table 8. Modeling according to scenarios of electricity generation by households in the studied countries.

\begin{tabular}{cccc}
\hline Regression Models & $\mathbf{a}$ & $\mathbf{b}$ & - \\
\hline YESI & 0.2313 & 1.5888 & - \\
YEII & 0.5232 & 1.906 & YEII \\
Scenario modeling & $\mathrm{x}$ & YESI & 1.0578 \\
Scenario 1 (10\%) & 0.2805 & 0.6770 & 1.1064 \\
Scenario 2 (20\%) & 0.3060 & 0.7175 & 1.1550 \\
Scenario 3 (30\%) & 0.3315 & 0.7580 & \\
\hline
\end{tabular}

Source: generated by the authors.

As shown by the calculations presented in Table 6, the third scenario, assuming an increase in household electricity production by $30 \%$, represents the best option according to the chosen criteria. For example, according to the criterion of energy dependence, one can note a decrease in the level of dependence as a result of electricity generation by households. Moreover, this decline has a rather slow pace. An increase in the volume of electricity generation by households for the studied countries by $1 \%$ can lead to a decrease in the level of a country's energy dependence by $11.2 \%$, as well as to an increase in energy security by $0.5 \%$. This is confirmed by the obtained results of the calculations: the hierarchical synthesis of the implementation of the third scenario is the most efficient and amounts to 0.1250. It helps to reduce energy dependence, since the value of the indicator under this scenario demonstrates the lowest level approaching zero (Table 9).

Table 9. Solution of the problem of nonlinear optimization by the Thomas L. Saaty method for the developed countries under study.

\begin{tabular}{|c|c|c|c|c|}
\hline Criterion & Assessment & Scenario 1 & Scenario 2 & Scenario 3 \\
\hline \multirow{3}{*}{ Energy security } & Initial (yesI) & 0.6770 & 0.7175 & 0.7580 \\
\hline & Normalized $\left(E S I_{s c i}^{n o r m}\right)$ & 0.3145 & 0.3333 & 0.3522 \\
\hline & $\begin{array}{c}\text { Weighted sum } \\
\left(E S I_{s c i}^{w s}=E S I_{s c i}^{n o r m} * \text { weight }\right)\end{array}$ & 1.8871 & 2.0000 & 2.1129 \\
\hline \multirow{3}{*}{ Energy dependence } & Initial $\left(\mathrm{y}_{\mathrm{EII}}\right)$ & 1.0578 & 1.1064 & 1.1550 \\
\hline & Normalized $\left(E I I_{s c i}^{n o r m}\right)$ & 0.3187 & 0.3333 & 0.3480 \\
\hline & $\begin{array}{c}\text { Weighted sum } \\
\left(E I I_{s c i}^{w s}=E I I_{s c i}^{n o r m} * \text { weight }\right)\end{array}$ & 0.0542 & 0.0567 & 0.0592 \\
\hline \multicolumn{2}{|c|}{$\begin{array}{c}\text { Hierarchical synthesis } \\
\left(H S_{s c i}=E S I_{s c i}^{n o r m} * E I I_{s c i}^{n o r m}\right)\end{array}$} & 0.1022 & 0.1133 & 0.1250 \\
\hline
\end{tabular}

Source: generated by the authors.

Assessment of the proposed methodology on the example of the studied countries demonstrated the excess of the criterion of energy dependence over the criterion of energy security. Household electricity production is based on renewable sources and can replace consumption from other energy sources. In fact, this is a reimbursement of one's own electricity consumption. A higher degree of influence of energy production by households on the level of energy dependence of the studied developed countries should be emphasized. For developing countries, the increase in energy production by households does not have a significant impact on the level of energy dependence due to the very low level of the Household Energy Independence Index and the corresponding volumes of energy production by them, which are not able to cover their needs in general. 


\section{Discussion}

The advantage of the study is the evidence that electricity generation by households is a factor in reducing the energy dependence of households on monopolists and the state as a whole. In addition, it can also have a significant impact on the balance of prices in the country's energy market [45]. At the same time, the state and market monopolists should not have leverage to prohibit or restrain the development of energy in this direction. The results obtained have significant implications for better understanding both the benefits and limitations of household electricity generation, which helps guide practical implementation. For the study countries, the overall benefit that could be derived from household electricity production depends on many factors, and the key is to make these supplies more affordable in the market through proactive energy management solutions for all residents, rather than focusing only on self-consumption of prosumers [4]. There are a lot of levers and mechanisms for solving this problem. Starting from a system of targeted concessional lending or compensation of interest on loans to an increase in electricity tariffs for the population. However, these steps should be woven into the overall strategy of state policy in the energy sector in general and the development of renewable energy sources in particular [46].

From the results of the study, namely the intensity of the impact of electricity generation by households on the level of energy independence, it is clear that alternative energy sources will not solve all energy problems in the coming years. However, focusing on them provides real opportunities to strengthen positions in the future, increase the country's energy security, and reduce the population's expenses for housing services [47]. In addition, despite the relatively high annual rate of increase in the use of renewable energy sources by households, there are a number of problems that impede its intensive development and the formation of household autonomy. Among the main constraints hindering the development of the subjects of this market are the norms for the installed capacity for power generating plants in private households determined by legislation, which slow down the growth rates of this sector. There are also legal restrictions on the types of facilities for renewable energy sources in private households with solar and wind installations [48]. Particularly acute for developing countries, there is the problem of high initial investment in the creation of new capacities on renewable energy sources for households [49]. However, with the development of the scale of electricity generation by households, one more problem is gradually being identified, which will worsen over time. It lies in the fact that an increase in the volume of capacities on renewable energy sources at the existing high rates of the "green" tariff will lead to a gradual increase in electricity prices in the state, since the compensation of the increased "green" tariffs is due to an increase in average prices for electricity obtained from both traditional and renewable sources [50]. It should be noted that these problems arise in many countries of the world, which have introduced economic incentives for the development of electricity generation by households from renewable sources. For example, some European countries have recently curtailed investment programs in renewable energy and reduced rates of "green" tariffs, citing the high cost of energy from renewable energy sources and the inexpediency of a significant increase in electricity tariffs to compensate for the "green" component [51].

This study proves that the development of renewable energy sources for households in developed countries under study is an important factor in increasing the level of energy security, reducing the use of fossil fuel resources (including imported ones), as well as reducing the negative impact of energy on the environment and improving the quality of life of citizens. A similar effect is not typical for developing countries, since renewable energy sources are most often economically more costly than traditional energy sources and fuels. However, along with future technological development, the cost of renewable energy will decrease, and its production will become more and more profitable [52]. Developing countries need to stimulate the development of renewable energy sources at the state level. The focus should be on those sources that have a high probability of economic return in the future and are the most promising from the point of view of production in the territory of a 
particular country. It is also required to localize the production of the necessary equipment to reduce the cost of renewable energy. It is essential to support the development and implementation of competitive production technologies and installations for renewable energy sources [53]. With reduced costs and favorable social policies, it is possible to develop renewable energy sources and create jobs [54,55].

The scientific contribution of this study is a comprehensive approach to assessing the degree of impact of household energy production on the energy security of countries, taking into account their level of development, as well as the social aspects that are valuable in the process of sustainable development. The study confirms that household energy production can reduce the energy dependence of countries, as well as increase the sustainability of their economic development. At the same time, a significant advantage of this study is the determination of the effect for countries with different levels of development. For most of the studied countries, the dependence of the country's energy security on households' energy independence can be traced. This confirms the impact of household energy production on the level of import-independence and energy storage capacity in a country [56]. For example, the positive impact of household energy production on the level of import-independence and energy storage capacity of developed countries has been identified and is negative for developing countries. The positive side of the research is the study of the relationship between the level of countries' energy independence and the index of households' energy independence. It was proved that an increase in energy production by households contributes to a decrease in energy dependence in developed countries. At the same time, the presence of this connection for developing countries was not observed. The regression analysis in this study was a significant addition to the toolkit for assessing and achieving the set objectives of the study. Thus, it was possible to determine the feasibility for countries with different developmental levels to increase the volume of households' renewable energy production for energy independence [57].

As household income and electricity price are the main determinants of demand, the projected results may vary from country to country. At the same time, the use of replacement fuels also affects the elasticity of electricity demand [58-60]; therefore, there are corresponding limitations of the study. This study confirms that access to free basic electricity and policies to improve access to electricity contribute to the expected outcome. This is due to an increase in the likelihood of households buying electricity and a reduction in overall energy costs [61,62]. Different levels of household income should be considered. Higher demand for electricity is characteristic of households rich in appliances in urban areas, especially if household members are large enough and they live in large dwellings [63]. For example, access to energy technologies in rural areas is significantly limited, which can lead to instability of the economy of this part of households and dependence on the monopoly of energy production by the state. Therefore, a significant advantage of this study is the formation of a basis for drawing more attention of the scientific world to the issue of energy independence of households, which will speed up its solution and the creation of independent sources of electricity in rural areas [64,65]. The solution to power supply of such households makes it possible to develop an antimonopoly system in the field of electrical production and create a basis for future research towards the comprehensive development of such territories. Future research may be based on expanding the number of countries under study in aggregate or for a specific region. Besides, in the future, this study can be deepened in the direction of assessing the effectiveness of household investment in projects for the production of electricity, and the volumes and terms of their payback in various countries and regions of the world. It is important to carry out further scientific research, which must be directed towards a quick and effective solution to the problems of the development of electricity production by households in order to increase their level of autonomy and energy independence of a country. The study can be developed in the field of economics and energy in the context of defining the position of various policies, using strategic levers and indicators that provide an effective response to energy security challenges in the regional and global markets. Expanding the spectrum of this study can 
help to quickly and efficiently solve the problems of developing electricity production by households in order to increase the level of their autonomy, energy independence of countries, and improve the quality of life of the population. This will make it possible, in the future, to ensure both the development of a country's economy and improve the life of its population.

\section{Conclusions}

The studied countries are characterized by a high interdependence between the increase in household energy consumption and the increase in household renewable energy consumption. For developed and developing countries, the trend is the development of household electricity production from renewable sources. At the same time, the quality of consumption changes, since households in this way substitute their part of the consumed energy.

For most of the studied countries, there is a dependence of a country's energy security on the energy independence of households. This confirms the impact of household energy production on the level of import independence and the capacity of energy storage in a country. At the same time, the positive impact of this relationship for developed countries and negative impact for developing countries were revealed. The main precondition for this is the very low energy independence of households with a high level of energy security in developing countries. The study of the relationship between the level of energy independence of countries and the index of energy independence of households made it possible to determine that an increase in energy production by households contributes to a decrease in energy dependence in developed countries. However, for developing countries, this relationship is absent. This made it possible to conduct a regression analysis only for a group of developed countries. Increasing the level of energy generation from renewable sources has no significant social impact in developing countries. However, for developed countries, households' renewable energy has an impact on the growth of social capital, living standards, health, and the external environment.

Based on the scenario modeling of the growth of electricity production by households in the studied developed countries, an analysis was carried out, as a result of which the third scenario, assuming an increase in electricity production by households by $30 \%$, is the best option in accordance with the selected criteria. Based on the criterion of Household Energy Independence Index, it becomes evident that countries' energy dependence decreases with the increase of households' electricity generation. At the same time, this decline is occurring at a rather slow pace. An increase in electricity generation by households for the studied countries can lead to a decrease in energy dependence, as well as to an increase in energy security. This is confirmed by the results of calculations based on the hierarchical synthesis of the implementation. The indicators of the third scenario characterize its maximum efficiency. It contributes to the reduction of energy dependence, since the value of the indicator in the scenario under consideration indicates that its level is approaching zero. At the same time, it can be stated that a further increase in electricity production by households will lead to an increase in energy efficiency in the context of energy dependence.

The solution of the formulated problem of nonlinear optimization by Thomas L. Saaty's method for the studied countries has demonstrated that the criterion of energy security is superior to the criterion of energy consumption per capita. Electricity production in households is based on renewable sources and can cover consumption from other energy sources. In fact, this is compensation for one's own energy consumption. At the same time, the level of energy consumption per capita will remain practically unchanged. The higher impact of household energy production on energy dependence should be emphasized. Therefore, it can be argued that the level of electricity production by households can reduce the energy dependence of countries as well as enhance the sustainability of their economic development. Hypothesis H1 is accepted because the influence of the Household Energy Independence Index on the Energy Security Index has been proven. H2 can only be adopted 
for developed countries. Developing countries have not yet reached the level of sufficient influence of household energy production on their energy independence.

In the future, this study can be deepened in the direction of assessing the effectiveness of household investment in projects for the production of electricity, and the volumes and terms of their payback in various countries and regions of the world. The proposed results can be claimed by responsible persons in the field of economics and energy in order to determine the position of various policies, and use strategic levers and indicators that ensure an effective response to energy security challenges in the regional and global markets. Expanding the range of this research can help to quickly and effectively solve the problems of developing electricity production by households in order to increase their level of autonomy, the energy independence of countries, and improve the quality of life of the populations.

Author Contributions: Conceptualization, I.P. and S.K.; methodology, S.B. and S.K.; software, I.P.; validation, S.B., I.P., and S.K.; formal analysis, S.K. and J.K.; investigation, S.B.; resources, I.P. and S.K.; data curation, S.B.; writing — original draft preparation, S.B.; writing — review and editing, I.P. and J.K.; visualization, S.K.; supervision, S.B.; project administration, I.P.; funding acquisition, S.K. and J.K. All authors have read and agreed to the published version of the manuscript.

Funding: This research received no external funding.

Institutional Review Board Statement: Not applicable.

Informed Consent Statement: Not applicable.

Data Availability Statement: Data will be available on request.

Conflicts of Interest: The authors declare no conflict of interest.

\section{References}

1. Mangla, S.K.; Luthra, S.; Jakhar, S.; Gandhi, S.; Muduli, K.; Kumar, A. A step to clean energy-Sustainability in energy system management in an emerging economy context. J. Clean. Prod. 2020, 242, 118462. [CrossRef]

2. IEA. Energy Access Outlook 2017: World Energy Outlook Special Report. 2017. Available online: https://www.iea.org/reports/ energy-access-outlook-2017 (accessed on 2 May 2021).

3. Gołębiowska, B.; Bartczak, A.; Czajkowski, M. Energy demand management and social norms. Energies 2020, 13, 3779. [CrossRef]

4. Li, Z.; Ma, T. Peer-to-peer electricity trading in grid-connected residential communities with household distributed photovoltaic. Appl. Energy 2020, 278, 115670. [CrossRef]

5. Katsuba, S.; Shestak, V.; Kvasnikova, T.; Bokov, Y. Liability for Violation of Environmental Legislation in the EU. Eur. Energ. Environm. Law Rev. 2021, 30, 9-19.

6. Park, S.; Kim, J. The effect of interest in renewable energy on US household electricity consumption: An analysis using Google Trends data. Renew. Energy 2018, 127, 1004-1010. [CrossRef]

7. Yang, T.; Ren, M.; Zhou, K. Identifying household electricity consumption patterns: A case study of Kunshan, China. Renew. Sust. Energy Rev. 2018, 91, 861-868. [CrossRef]

8. Taghizadeh-Hesary, F.; Yoshino, N. The way to induce private participation in green finance and investment. Financ. Res. Lett. 2019, 31, 98-103. [CrossRef]

9. Inderberg, T.H.J.; Tews, K.; Turner, B. Is there a prosumer pathway? Exploring household solar energy development in Germany, Norway, and the United Kingdom. Energy Res. Soc. Sci. 2018, 42, 258-269. [CrossRef]

10. McKenna, R. The double-edged sword of decentralized energy autonomy. Energy Policy 2018, 113, 747-750. [CrossRef]

11. Domenech, B.; Ferrer-Martí, L.; Lillo, P.; Pastor, R.; Chiroque, J. A community electrification project: Combination of microgrids and household systems fed by wind, PV or micro-hydro energies according to micro-scale resource evaluation and social constraints. Energy Sustain. Dev. 2014, 23, 275-285. [CrossRef]

12. Samad, H.; Zhang, F. Electrification and Household Welfare: Evidence from Pakistan; The World Bank: Washington, DC, USA, 2018.

13. Lee, K.; Brewer, E.; Christiano, C.; Meyo, F.; Miguel, E.; Podolsky, M.; Rosa, J.; Wolfram, C. Electrification for "under grid" households in rural Kenya. Dev. Eng. 2016, 1, 26-35. [CrossRef]

14. Wittenberg, I.; Matthies, E. Solar policy and practice in Germany: How do residential households with solar panels use electricity? Energy Res. Soc. Sci. 2016, 21, 199-211. [CrossRef]

15. Androniceanu, A.; Popescu, C.R. An inclusive model for an effective development of the renewable energies public sector. Adm. Public Manag. Rev. 2017, 28, 81-96.

16. Tvaronavičienė, M.; Ślusarczyk, B. Energy Transformation Towards Sustainability; Elsevier: Amsterdam, The Netherlands, 2019. 
17. Siemiątkowski, P.; Tomaszewski, P.; Marszałek-Kawa, J.; Gierszewski, J. The financing of renewable energy sources and the level of sustainable development of Poland's provinces in the area of environmental order. Energies 2020, 13, 5591. [CrossRef]

18. De Fatima, M.; Arthur, S.R.; Cockerill, A. The roles of government and the public utility in achieving universal access to electricity. Econ. Energy Environ. Policy 2019, 8, 1-7. [CrossRef]

19. Hasanov, F.J.; Mahmudlu, C.; Deb, K.; Abilov, S.; Hasanov, O. The role of Azeri natural gas in meeting European Union energy security needs. Energy Strategy Rev. 2020, 28, 100464. [CrossRef]

20. Aslanturk, O.; Kiprizlı, G. The role of renewable energy in ensuring energy security of supply and reducing energy-related import. Int. J. Energy Econ. Policy 2020, 10, 354. [CrossRef]

21. Rodríguez-Fernández, L.; Carvajal, A.B.F.; Ruiz-Gómez, L.M. Evolution of European Union's energy security in gas supply during Russia-Ukraine gas crises (2006-2009). Energy Strategy Rev. 2020, 30, 100518. [CrossRef]

22. Azzuni, A.; Breyer, C. Global energy security index and its application on national level. Energies 2020, 13, 2502. [CrossRef]

23. Azzuni, A.; Breyer, C. Definitions and dimensions of energy security: A literature review. Wiley Interdiscip. Rev. Energy Environ. 2018, 7, e268. [CrossRef]

24. Šprajc, P.; Bjegović, M.; Vasić, B. Energy security in decision making and governance-Methodological analysis of energy trilemma index. Renew. Sustain. Energy Rev. 2019, 114, 109341. [CrossRef]

25. Szulecki, K. Securitization and state encroachment on the energy sector: Politics of exception in Poland's energy governance. Energy Policy 2020, 136, 111066. [CrossRef]

26. Proskuryakova, L. Updating energy security and environmental policy: Energy security theories revisited. J. Environ. Manage. 2018, 223, 203-214. [CrossRef] [PubMed]

27. Zhao, Z.J.; Su, G.; Li, D. The rise of public-private partnerships in China. J. Chin. Gov. 2018, 3, 158-176. [CrossRef]

28. Shahbaz, M.; Raghutla, C.; Song, M.; Zameer, H.; Jiao, Z. Public-private partnerships investment in energy as new determinant of CO2 emissions: The role of technological innovations in China. Energy Econ. 2020, 86, 104664. [CrossRef]

29. Butu, H.M.; Nsafon, B.E.K.; Park, S.W.; Huh, J.S. Leveraging community based organizations and fintech to improve small-scale renewable energy financing in sub-Saharan Africa. Energy Res. Soc. Sci. 2021, 73, 101949. [CrossRef]

30. Raza, S.A.; Shah, S.H.; Yousufi, S.Q. The impact of public-private partnerships Investment in Energy on carbon emissions: Evidence from nonparametric causality-in-quantiles. Environ. Sci. Pollut. Res. 2021, 28, 23182-23192. [CrossRef]

31. Wojewnik-Filipkowska, A.; Wegrzyn, J. Understanding of public-private partnership stakeholders as a condition of sustainable development. Sustainability 2019, 11, 1194. [CrossRef]

32. Zhao, X.; Luo, D. Driving force of rising renewable energy in China: Environment, regulation and employment. Renew. Sustain. Energy Rev. 2017, 68, 48-56. [CrossRef]

33. Bridge, G.; Özkaynak, B.; Turhan, E. Energy infrastructure and the fate of the nation: Introduction to special issue. Energy Res. Soc. Sci. 2018, 41, 1-11. [CrossRef]

34. MacDonald, S.; Eyre, N. An international review of markets for voluntary green electricity tariffs. Renew. Sust. Energy Rev. 2018, 91, 180-192. [CrossRef]

35. Gwerder, Y.V.; Marques, P.; Dias, L.C.; Freire, F. Life beyond the grid: A life-cycle sustainability assessment of household energy needs. Appl. Energy 2019, 255, 113881.

36. United Nations. World Economic Situation Prospects. 2020. Available online: https://www.un.org/development/desa/dpad/ wp-content/uploads/sites/45/WESP2020_Annex.pdf (accessed on 2 May 2021).

37. World Energy Council. Energy Trilemma Index. 2020. Available online: https://trilemma.worldenergy.org/\#!/energy-index (accessed on 2 May 2021).

38. Knoema. Energy Trilemma Index. 2020. Available online: https://knoema.com/search?query=trilemma+index\&pageIndex= \&scope $=\&$ term $=\&$ correct $=\&$ source$=$ Header (accessed on 2 May 2021).

39. International Renewable Energy Agency. Final Renewable Energy Consumption. 2018. Available online: https://www.irena.org/ Statistics/View-Data-by-Topic/Renewable-Energy-Balances/Final-Renewable-Energy-Consumption (accessed on 2 May 2021).

40. International Energy Agency. Data and Statistics. 2020. Available online: https://www.iea.org/data-and-statistics?country= WORLD\&fuel=Energy\%20supply\&indicator=TPESbyPop (accessed on 2 May 2021).

41. Reshetnikova, I.; Shvydanenko, H.; Boichenko, K. Determinants to provide the efficiency of integrated development of the light industry enterprises. Mark. Manag. Innov. 2020, 3, 157-169. [CrossRef]

42. Our World in Data. Share of Primary Energy from Renewable Sources. 2020. Available online: https://ourworldindata.org/ grapher / renewable-share-energy?tab=chart\&stackMode=absolute\&time=earliest..2018\&country=AZE $\sim\{\}$ MEX \&region=World (accessed on 2 May 2021).

43. Legatum Institute Foundation. The Legatum Prosperity Index 2019. A tool for transformation. 2020. Available online: https:/ /li.com/reports/2019-legatum-prosperity-index/\#: \{\}:text=The\%20Legatum\%20Prosperity $\% 20$ Index $\%$ E2\%84\%A2 ,drive\%20tangible\%20improvements\%20in\%20prosperity (accessed on 2 May 2021).

44. Khachaturyan, A.A.; Khachaturyan, K.S.; Shirkin, A.A. Development of Russia's regions in the conditions of the digital economy: Management, effectiveness, and competitiveness. In State and Corporate Management of Region's Development in the Conditions of the Digital Economy; Springer: Cham, Switzerland, 2021; pp. 25-29.

45. Dźwigoł, H.; Dźwigoł-Barosz, M.; Zhyvko, Z.; Miśkiewicz, R.; Pushak, H. Evaluation of the energy security as a component of national security of the country. J. Secur. Sustain. Issues 2019, 8, 307-317. [CrossRef] 
46. Galvin, R.; Sunikka-Blank, M. Economic inequality and household energy consumption in high-income countries: A challenge for social science based energy research. Ecol. Econ. 2018, 153, 78-88. [CrossRef]

47. Wei, T.; Wang, X. Rebound effect from income savings due to an energy efficiency improvement by households: An input-output approach. Energies 2020, 13, 4044. [CrossRef]

48. Mrówczyńska, M.; Skiba, M.; Bazan-Krzywoszańska, A.; Sztubecka, M. Household standards and socio-economic aspects as a factor determining energy consumption in the city. Appl. Energy 2020, 264, 114680. [CrossRef]

49. Vasseur, V.; Marique, A.F.; Udalov, V. A conceptual framework to understand households' energy consumption. Energies 2019, 12, 4250. [CrossRef]

50. Herbes, C.; Rilling, B.; MacDonald, S.; Boutin, N.; Bigerna, S. Are voluntary markets effective in replacing state-led support for the expansion of renewables?-A comparative analysis of voluntary green electricity markets in the UK, Germany, France and Italy. Energy Policy 2020, 141, 111473. [CrossRef]

51. Hannesson, R. How much do European households pay for green energy? Energy Policy 2019, 131, 235-239. [CrossRef]

52. Lin, B.; Zhu, J. The role of renewable energy technological innovation on climate change: Empirical evidence from China. Sci. Total Environ. 2019, 659, 1505-1512. [CrossRef]

53. Ye, B.; Zhang, K.; Jiang, J.; Miao, L.; Li, J. Towards a 90\% renewable energy future: A case study of an island in the South China Sea. Energy Convers. Manag. 2017, 142, 28-41. [CrossRef]

54. Sen, S.; Ganguly, S. Opportunities, barriers and issues with renewable energy development-A discussion. Renew. Sustain. Energy Rev. 2017, 69, 1170-1181. [CrossRef]

55. Polzin, F.; Egli, F.; Steffen, B.; Schmidt, T.S. How do policies mobilize private finance for renewable energy?-A systematic review with an investor perspective. Appl. Energy 2019, 236, 1249-1268. [CrossRef]

56. Haseeb, M.; Kot, S.; Iqbal Hussain, H.; Kamarudin, F. The natural resources curse-economic growth hypotheses: Quantile-onQuantile evidence from top Asian economies. J. Clean. Prod. 2021, 279, 123596. [CrossRef]

57. Hussain, H.I.; Slusarczyk, B.; Kamarudin, F.; Thaker, H.M.T.; Szczepańska-Woszczyna, K. An investigation of an adaptive neuro-fuzzy inference system to predict the relationship among energy intensity, globalization, and financial development in major ASEAN economies. Energies 2020, 13, 850. [CrossRef]

58. Pena-Bello, A.; Barbour, E.; Gonzalez, M.C.; Yilmaz, S.; Patel, M.K.; Parra, D. How does the electricity demand profile impact the attractiveness of PV-coupled battery systems combining applications? Energies 2020, 13, 4038. [CrossRef]

59. Nasr, A.K.; Kashan, M.K.; Maleki, A.; Jafari, N.; Hashemi, H. Assessment of barriers to renewable energy development using stakeholders approach. Entrep. Sustain. Issues 2020, 7, 2526-2541. [CrossRef]

60. Tvaronavičienè, M.; Plèta, T.; Della Casa, S.; Latvys, J. Cyber security management of critical energy infrastructure in national cybersecurity strategies: Cases of USA, UK, France, Estonia and Lithuania. Insights Reg. Dev. 2020, 2, 802-813. [CrossRef]

61. Muhumuza, R.; Zacharopoulos, A.; Mondol, J.D.; Smyth, M.; Pugsley, A. Energy consumption levels and technical approaches for supporting development of alternative energy technologies for rural sectors of developing countries. Renew. Sust. Energ. Rev. 2018, 97, 90-102. [CrossRef]

62. El Iysaouy, L.; El Idrissi, N.E.; Tvaronavičienè, M.; Lahbabi, M.; Oumnad, A. Towards energy efficiency: Case of Morocco. Insights Reg. Dev. 2019, 1, 259-271. [CrossRef]

63. Ye, Y.; Koch, S.F.; Zhang, J. Determinants of household electricity consumption in South Africa. Energy Econ. 2018, 75, 120-133. [CrossRef]

64. Grondys, K.; Androniceanu, A.; Dacko-Pikiewicz, Z. Energy management in the operation of enterprises in the light of the applicable provisions of the Energy Efficiency Directive (2012/27/EU). Energies 2020, 13, 4338. [CrossRef]

65. Tishkov, S.; Shcherbak, A.; Karginova-Gubinova, V.; Volkov, A.; Tleppayev, A.; Pakhomova, A. Assessment the role of renewable energy in socio-economic development of rural and Arctic regions. Entrep. Sustain. Issues 2020, 7, 3354-3368. [CrossRef] 